\title{
PERBEDAAN MARATIB TA'DIL DI KALANGAN ULAMA HADIS
}

\author{
Mina Mudrikah Zain \\ Mahasiswa Fakultas Ushuluddin UIN Sunan Gunung Djati Bandung \\ Jl. AH. Nasution No. 105, Bandung, Indonesia \\ E-Mail: minamudrikahzain@gmail.com
}

\begin{abstract}
Abstrak
Dalam wacana kajian hadis salah satu yang dibahas adalah perbedaan tingkat keadilan perawi hadis. Para ulama hadis telah menentukan istilah-istilah untuk menyifati karakteristik para rawi, dari segi diterima atau tidaknya periwayatannya. Suatu jalur periwayatan hanya dapat diterima bila memenuhi kriteria keadilan periwayatnya. Masalahnya, perawi yang disifati dengan karakteristik seperti apakah yang dikatakan sebagai perawi yang adil ? Tulisan pada artikel ini hendak mengulas dan mendiskusikan kembali wacana maratib ta'dil di kalangan ulama hadis. Sehingga, dari perbedaan maratib ta'diltersebut, dapat diketahui implikasinya terhadap kriteria hadis dan kehujjahannya sebagai istinbath hukum.

Kata Kunci:Hadis; Maratib Ta'dil; Ulama Hadis; Lafazh Ta'dil; Hujjah.
\end{abstract}

\section{A. PENDAHULUAN}

Sebagai umat Islam, tentunya kita sudah tahu bahwa hadis merupakan sumber kedua setelah al-Qur'an, sehingga hadis sangat diperlukan untuk memperjelas ayatayat al-Qur'an yang belum jelas maknanya. Oleh karena itu hadis atau sunnah Nabi mempunyai kedudukan yang penting sebagai sumber ajaran Islam, selain al-Qur'an.

Proses penulisan hadis berlangsung setelah Nabi wafat dan peresmiannya 200 tahun setelah Nabi wafat. Dalam rentang waktu yang panjang itu, kemungkinan terjadinya pemalsuan dan perubahan yang sangat besar, serta menimbulkan berbagai hal yang dapat menjadikan para periwayat hadis menyalahi apa yang sebenarnya barasal dari Nabi. Maka dari itu perlu adanya ilmu alJarh wa al-Ta'dil.

Para ulama hadis telah menentukan istilah-istilah yang mereka pergunakan untuk menyifati karakteristik para rawi, dari segi diterima atau tidaknya riwayat hadisnya. Dengannya mereka ingin menunjukkan klasifikasi al-jarh wa ta'dil tidaklah diragukan bahwa mengetahui istilah-istilah tersebut sangat penting bagi pencari dan peneliti hadis, mengingat ia merupakan kunci ungkapan yang akan mengenalkan kita pada kondisi rawi. ${ }^{1}$ Namun, para ulama berbeda

\footnotetext{
${ }^{1}$ Nuruddin 'Itr, 'Ulumul Hadis, trans. Dr. Mujiyo "Manhaj an-Naqd fii 'Uluum alHadits"(Bandung: Remaja Rosdakarya, 2014), 98.
}

pendapat dalam menentukan martabat ta'dil. Dengan demikian, dalam makalah ini akan dijelaskan mengenai perbedaan-perbedaan tersebut. Karena, mengetahui martabat ta'dil merupakan problematika yang tidak dapat diabaikan dalam menilai keadaan seorang rawi. Dan hal tersebut sangat urgen dalam menentukan kriteria bahkan kehujahan suatu hadis dapat diterima atau ditolak.

\section{B. PEMBAHASAN}

\section{Perbedaan Jumlah Maratib Ta'dil di Kalangan Ulama Hadis}

Sebelum mengetahui maratib ta'dil, akan dibahas sekilas pengertian dari ta'dil. Sebagaimana diketahui bahwa pengertian ta'dil menurut bahasa artinya meluruskan, membetulkan, membersihkan. Sedangkan ta'dil menurut ilmu hadis adalah menunjukkan atau membayangkan kebaikan atau kelurusan seorang rawi, apakah semua itu benar ada pada diri si rawi atau tidak. Nur ad-Din memberikan definisi ta'dil dengan:

$$
\text { ضابط هو تزكية الراوي والحلكم عليه بأنه عدل أو }
$$

"Yaitu pembersihan atau pensucian perawi dan ketetapan,bahwa ia "adil atau dhabith.",

Para ahli berbeda pendapat dalam menentukan martabat ta'dil. Berikut ini akan dikemukakan tiga pendapat para ahli tersebut

2 Drs. Totok Jumantoro, Kamus Ilmu Hadits, (Jakarta: Bumi Aksara, 2002), 96. 
yang tercantum pada kitab karangannya masing-masing.

Imam Ibn Abi Hatim al-Razi, beliau menjelaskan pendapatnya dalam kitabnya alJarh wa al-Ta'dil. Kemudian Ibn Shalah dalam Ulum al-Hadis dan al-Nawawi dalam al-Taqrib-nya. Mereka semua membagi tingkatan jarh wa ta'dil atas empat bagian. ${ }^{3}$

Menurut al-Hafidh ad-Dzahaby dan al'Iraqy menjadi 5 tingkatan. ${ }^{4}$ Kedua ulama tersebut menjelaskan pendapatnya dalam karangannya masing-masing. Al-Dzahaby dalam Mizan al-'Itidal dan al-'Iraqy dalam al-Fiyahnya. ${ }^{5}$

Imam Ibn Hajar al-Asqalani, dalam Taqrib al-Tahdzib membagi martabat jarh dan ta'dil atas dua belas martabat. Namun, apabila diperinci martabat itu masing-masing akan menjadi enam martabat yaitu enam martabat untuk jarh dan enam martabat untuk ta'dil. Imam al-Suyuthi mengikuti pendapat Ibn Hajar dengan sedikit penambahan di samping beliau lebih jelas dalam merincinya. ${ }^{6}$

Berikut penjelasan maratib ta'dil di kalangan Ulama hadis:

\section{a. Martabat-Martabat Ta'dil Menurut al- Razi}

Para ulama telah banyak menulis tentang klasifikasi para rawi. Mereka berupaya keras untuk membaginya dan menjelaskan status-statusnya. Tulisan yang pertama kali sampai kepada kita (Nuruddin 'Itr, hlm. 99), adalah karya tokoh kritikus alImam bin al-Imam Abdurrahman bin Abi Hatim al-Razi (w. $327 \mathrm{H}$ ), dalam kitabnya yang besar al-Jarh wa 'al-Ta'dil. Ia telah menyusun martabat al-Jarh wa al-Ta'dil masing-masing terdiri atas empat martabat, di antaranya sebagai berikut: ${ }^{7}$

${ }^{3}$ M. Abdurrahman dan Elan Sumarna, Metode Kritik Hadis, (Bandung: Remaja Rosdakarya, 2011), 152.

${ }^{4}$ Fatchur Rahman, Ikhtisar Mushthalahu'l Haits, (Bandung: al-Ma'arif, 1974), 313.

${ }^{5}$ M. Abdurrahmandan Elan Sumarna, Metode Kritik Hadis, 152.

${ }^{6}$ M. Abdurrahman dan Elan Sumarna, Metode Kritik Hadis, 152.

${ }^{7}$ Nuruddin 'Itr, 'Ulumul Hadis, 99.
1. Apabila dikatakan bagi seseorang bahwa ia Tsiqat, Mutqin, atau Tsabtun, maka ia adalah orang yang hadisnya dapat dipakai hujah.

2. Apabila dikatakan baginya Shuduq, Mahalluhu ash-Shidqu, atau 'Laa Ba'sa $B i h$, maka ia adalah orang yang hadisnya dapat ditulis dan diperhatikan. Ia menempati tingkatan kedua;

3. Apabila dikatakan baginya Syaikh, maka ia menempati tingkatan ketiga, hadisnya dapat ditulis dan diperhatikan tetapi di bawah tingkatan kedua.

4. Apabila para ulama mengatakan Shalih al-Hadis, maka hadisnya dapat ditulis untuk $i^{\prime}$ tibar. ${ }^{8}$

Banyak ulama hadis yang mengikuti jejak al-Razi dalam mengklasifikasi al-Jarh wa al-Ta'dil ini. Diantaranya adalah Ibnu ash-Shalah dan al-Nawawi. Mereka mengikutinya tanpa menyalahinya sedikit pun.

\section{b. Martabat-Martabat Ta'dil Menurut al- Suyuthi}

Adapun mengenai martabat ta'dil Imam Suyuthi membaginya atas 6 tingkatan. Hal ini sebagaimana dalam al-Fiyahnya yang dikutip oleh Muhammad Mahfuzh alTarmasi dalam kitabnya Manhaj Dzawin Nazhar. ${ }^{10}$

Jika pendapat al-Suyuthi di atas diperinci dan kemudian digabungkan pula dengan pendaat ulama lainnya dalam menilai martabat ta'dil, maka martabat itu akan tersusun sebagai berikut: ${ }^{11}$

1. Setiap lafal yang menunjukkan keadilan dan keteguhan rawi, di sini muhadditsin menggunakan shighat af'al tafdhil atau

${ }^{8}$ I'tibar dalam pengertian sederhana adalah serangkaian kegiatan meneliti personalia sanad-sanad suatu hadits tertentu yang salah satu sanadnya telah ditemukan, untuk mengetahui jumlah sanad yang sebenarnya, yaitu untuk mengetahui apakah ada syaahid dan taabi' (mutaaba'ah) bagi sanad yang pertama ditemukan.

${ }^{9}$ Nuruddin 'Itr, 'Ulumul Hadis, 100 .

${ }^{10} \mathrm{M}$. Abdurrahmandan Elan Sumarna, Metode Kritik Hadis, 154.

${ }^{11}$ M. Abdurrahmandan Elan Sumarna, Metode Kritik Hadis, 154-156. 
dengan mempergunakan shighat yang menunjukkan sifat terpuji yang tiada bandingannya bagi rawi itu. Lafal ta'dil ini merupakan shighat yang paling tinggi nilainya, kuat dan kokoh kedudukannya dan istimewa pula martabatnya. Karena itu, rawi yang mendapat julukan ini adalah rawi yang paling adil, sangat jujut, dan sangat teguh.

2. Setiap lafal yang menunjukkan kebenaran rawi, keteguhan, ketsiqatan, kejujuran dan keadilannya; ini dengan mempergunakan lafal yang sama dengan yang sebelumnya atau dengan mempergunakan kata lain yang semaksud dan semakna dengan makna yang pertama. Dengan pengulangan lafal yang makin sering dan makin banyak akan menunjukkan martabat rawi itu lebih kuat dan lebih tinggi nilainya, bila dibandingkan dengan penilaian yang tidak diulang lafalnya.

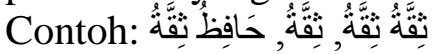

3. Setiap lafal yang menunjukkan kekokohan, keteguhan, keadilan dan kepercayaan rawi. Adakalanya pula mempergunakan kata-kata pejian yang senilai dengan kekokohan di atas. Lafal tersebut ialah: Tsiqatun, Muttaqinun, Imaamun, Tsaabitu al-Qalbi wa al-Lisaan wa al-Hujjati, Haafizhun Dhaabitun.

4. Setiap lafal yang menunjukkan kepada derajat rawi dengan mempergunakan satu lafal saja, baik lafal yang menunjukkan keadilan, kekokohan dan kebenaran rawi. Akan tetapi diberi jaminan bahwa rawi tersebut, kekokohan, keteguhan dan keadilannya itu sekokoh pada tingkatan sebelumnya. Lafal tersebut ialah: Shaduuqun, Laa Ba'sa Bihi, Khiyaar anNaas Ma'muunun Laisa Bihi Ba'sun, Khiyaar al-Khalq.

5. Setiap lafal yang menunjukkan baik, benar dan jujurnyarawi. Dengan tidak menunjukkan bahwa hafalan, kejujuran dan keadilannya itu dapat dipastikan. Lafal-lafal tersebut ialah: Shalih al-Hadis, Wasath, Yuktabu Hadiitsuhu, Jayyid alHadis, Syaikh, Muqaarab al-Hadis.

6. Setiap lafal yang menunjukkan derajat rawi, dengan mempergunakan suatu lafal dengan lafal tersebut di atas kemudian diiringi kata-kta yang tidak menunjukkan keteguhan lafal-lafal itu. Malahan hanya merupakan pengharap saja dari kejujuran dan keteguhan rawi itu. Lafal tersebut ialah: Shaduq Insya Allah, Laisa bi Ba'idin min al-Shawab, Shuwailah,Maqbul.

Imam al-Suyuthi tidak memasukkan martabat sahabat ke dalam martabat ta'dil ini, akan tetapi memasukkan af'al tafdhil sebgai gantinya. Kemungkinan besar alasan utama beliau tidak memasukkan sahabat kepada martabat ta'dil karena sahabat tidak perlu diperbincangkan kejujurannya. ${ }^{12}$

\section{c. Martabat-Martabat Ta'dil Menurut al-Dzahaby}

Al-Dzahaby menjelaskan dalam pendahuluan kitab Mizan al-I'tidaal-nya: ${ }^{13}$

1. Tingkatan rawi yangditerima hadisnya yang paling tinggi adalah mereka yang mendapat julukan TsabtunHujjatun, Tsabatun Hafizhun, Tsiqatun, Mutqinun, atau Tsiqatun tsiqat;

2. Kemudian yang diberi julukan Tsiqatun;

3. Kemuian yang diberi julukan Shaduq, Laa Ba'sa Bih, dan Laisa bihi Basun;

4. Kemudian yang diberi julukan Mahalluhu ash-Shidq, Jayyid al-Hadis, Shalih alHadis, Syaikh Wasath, Syaikh Hasan alHadis, Shaduq Insya Allah, Shuwailih, dan sebagainya.

Dengan demikian, al-Dzhaby menambahkan satu tingkat lagi yang lebih tinggi daripada tingkatan pertama menurut Ibnu Abi Hatim, dan ia menjadikan tingkatan ketiga dan tingkatan keempat menjadi satu tingkatan.

\section{d. Martabat-Martabat Ta'dil Menurut Ibnu Hajar}

Adapun tingkatan ta'dil menurut Ibnu Hajar, sebagai berikut: ${ }^{14}$

1. Segala sesuatu yang menggunakan martabat keadilan yang lebih tinggi. Hal

\footnotetext{
${ }^{12}$ M. Abdurrahmandan Elan Sumarna, Metode Kritik Hadis, 154-156.

${ }^{13}$ Nuruddin 'Itr, 'Ulumul Hadis, 100.

${ }^{14}$ M. Abdurrahmandan Elan Sumarna, Metode Kritik Hadis, 158-159.
} 
ini biasanya dengan menggunakan af'al al-mubalaghah.

2. Memperkuat ke-tsiqat-an rawi dengan mengulang-ulang lafal yang sama atau semakna dengannya. Seperti lafal Tsiqatun tsiqatun (orang yang tsiqat (lagi) tsiqat).

3. Menunjuk keadilan dengan lafal yang mengandung arti kuat ingatan. Seperti lafal tsabata (orang yang teguh hati dan lidahnya).

4. Menunjuk ke-tsiqat-an tetapi dengan lafal yang tidak mengandung arti tsiqat. Contoh : Shaduqun (orang yang sangat jujur).

5. Menunjukkan kejujuran rawi, tetapi tidak terpahamkan adanya ke-dhabit-an. Contoh: Jayyid al-Hadis (orang yang baik hadisnya).

6. Menunjuk arti mendekati cacat, biasanya dengan menambahkan lafal Insya Allah, atau dengan men-tashgir-kan, atau dengan mengaitkannya pada suatu pengharapan.

\section{Al-Hafizh Ibnu Hajar al-Asqalani dalam kitabnya al-Nukhbah beliau menambahkan dalam ta'dil satu martabat lagi yang lebih tinggi dari pada martabat yang ditambahkan oleh al-Dzahaby dan al-'Iraqi, yaitu tingkatan yang dijuluki dengan bentuk kata af'al al-Tafdhil, seperti Ausaq an-Naas. Dengan demikian, martabat ta'dil menjadi lima. Dan ia menambahinya lagi dalam kitab Tahzhib at-Tahzhib dan Taqrib al-Tahzhib satu martabat yang lebih tinggi lagi, yakni martabat sahabat, sehingga martabat ta'dil menjadi enam. Tindakan al-Hafizh menyebutkan martabat sahabat sebagai martabat tersendiri itu sangat rasional, karena kredibilitas mereka dijelaskan oleh nash al- Qur'an maupun hadis, dan ta'dil keduanya itu lebih tinggi daripada ta'dil oleh manusia. $^{15}$}

\section{Perbedaan Pendapat Ulama Hadis Tentang Maratib Ta'dil Terhadap Kriteria Hadis dan Kehujahannya}

Al-'Iraqi yang mengikuti al-Dzahaby
dalam pembagian al-Jarh wa al-Ta'dil.

\footnotetext{
${ }^{15}$ Nuruddin 'Itr, 'Ulumul Hadis, 101.
}

Beliau lebih memerinci dan menjelaskan, dengan mencantumkan kata-kata martabat pertama, martabat kedua, dan seterusnya sebagai ganti kata kemudian (tsumma). Di samping itu beliau juga menyebutkan lebih banyak lafazh-lafazh julukan pada setiap martabat serta menjelaskan hukum masingmasing martabat. ${ }^{16}$

Sebagian ulama berpendapat bahwa hadis shahih itu hanyalah hadis yang diriwayatkan oleh rawi yang sifat dengan martabat ta'dil dari nomor satu sampai nomor tiga. Martabat keempat termasuk katagori hadis hasan, sedangkan martabat kelima dan keenam termasuk katagori hadis dha'if. Ibnu Mahdi, Ibnu Ma'in, Ibnu Abi Hatim dan abu Zur'ah memandang bahwa yang termasuk katagori hadis shahih itu rawi hadis yang disifati oleh martabat kesatu sampai keempat. Sedangkan hadis yang diriwayatkan oleh rawi yang ada pada martabat kelima dan keenam, ulama tidak dapat begitu saja menerimanya; katagori hadis ini belum jelas kedudukannya; karena perlu mendapat pengujian terlebih dahulu. Hadis yang termasuk katagori ini dapat diterima sebagai i'tibar (contoh) yang perlu di-ikhtibar (diuji). ${ }^{17}$

Sebagian ulama berpendapat pula bahwa hadis pada martabat kelima dan keenam maqbul (diterima) dan ma'mul (diamalkan). Hal ini bila ada syahid (saksi) hadis shahih yang lain atau hadis lain yang semartabat pula dengannya. Dan karenanya, hadis yang termasuk pada kedua martabat ta'dil ini bisa menjadi hadis hasan li ghayrihi dan atau malah hadis hasan li dzatihi. $^{18}$

Imam Al-Sakhawi dalam Fath alMughits menegaskan bahwa hadis pada martabat kelima dam keenam harus diteliti kembali secara saksama di antara para ahli menilai bahwa rawi ada pada yang kedua

\footnotetext{
${ }^{16}$ Nuruddin 'Itr, 'Ulumul Hadits, 101.

${ }^{17}$ M.Abdurrahman dan Elan Sumarna, Metode Kritik Hadis, 156.

${ }^{18}$ M.Abdurrahman dan Elan Sumarna, Metode Kritik Hadis, 157.
} 
martabat terakhir ini masih dipertimbangkan dan dipermasalahkan riwayatnya. Pokok persoalannya, karena pada fardhiyah (asumsi) bahwa rawi itu masih rendah atau belum sampai kepada derajat tsiqat; dan bila dinilai tajrih. Hadis ini ditulis dan diterima. Ada yang mengamalkan kepada hadis ini karena ikhtiyath (hati-hati). Demikian diantara pendapat yang dikemukakan oleh ulama sehubungan dengan penetapan dalil dan martabat-martabat tersebut.

Imam al-Dzahaby memberikan penerangan bahwa para ahli berbeda pendapat dalam menentukan klasifikasi dan nomerisasi jarh dan ta'dil, namun pada dasarnya perbedaan tersebut tidak ada yang prinsipil. Malahan satu sama lain sebenarnya saling melengkapi dan saling sempurna menyempurnakan.

Dari pernyataan di atas dapat disimpulkan bahwa, para rawi pada empat martabat pertama dapat dipakai hujah. Adapun menurut Drs. H. Ayat Dimyati menyebutkan ketiga martabat pertama saja yang dapat dijadikan hujah. ${ }^{19}$ Sedangkan para rawi pada martabat-martabat berikutnya tidak dapat dipaki hujah; karena lafazh-lafazh julukan bagi mereka tidak menunjukkan tanda-tanda ke-dhabith-an. Namun hadis meraka ditulis untuk i'tibar. Adapun rawi pada martabat keenam hukumnya lebih rendah dari rawi pada martabat sebelumnya. Sebagian dari mereka dapat ditulis hadisnya untuk i'tibar tanpa diteliti ke-dhabith-annya lantaran ihwal perkaranya yang telah jelas. Demikian dikatakan oleh al-Sakhawi. ${ }^{20}$

\footnotetext{
${ }^{19}$ Ayat Dimyati, Pengantar Studi Sanad Hadits,
} (Bandung: Fakultas Syari'ah IAIN Sunan Gunung Djati, t.t), 34 .

${ }^{20}$ Nuruddin 'Itr, 'Ulumul Hadis, 103.
Hadis-hadis para rawi yang di-ta'dilkan menurut tingkatan kelima dan keenam hanya dapat ditulis dan baru dapat dipergunakan bila dikuatkan oleh hadis periwayatan lain. $^{21}$ Adapun menurut pendapat lain, Martabat yang keenam tidak bisa dijadikan hujjah karena keahliannya, tetapi hadisnya ditulis hanya sebagai bahan pertimbangan, tetapi tidak diperiksa karena sudah jelas mereka itu tidak dhabith. ${ }^{22}$

Nuruddin 'Itr dalam bukunya menjelaskan bahwa, hukum ini relevan dengan klasifikasinya sebagaimana dapat dijumpai dalam penjelasannya yang sesuai dengan pendapat yang dinyatakan oleh Ibnu Hatim dan diakui oleh Ibnu al-Shalah dalam hal klasifikasi martabat-martabat ta'dil.

Mereka sepakat bahwa orang yang dijuluki dengan kata shuduq tidak dapat dipakai hujah kecuali setelah diteliti dan dipelajari apakah kuat hafalannya terhadap hadis atau tidak. ${ }^{23}$

Kesepakatan ini menolak anggapan sebagian ulama yang mengatakan bahwa periwayat yang dijuluki dengan shuduq itu hadisnya dapat dipakai hujah dan termasuk hadis hasan lidzatihi, tanpa harus diteliti lebih dahulu.

\footnotetext{
${ }^{21}$ M. Solahudin dan Agus Suyadi, Ulumul Hadis, (Bandung: Pustaka Setia, 2013), 166.

${ }^{22}$ Ayat Dimyati,Pengantar Studi Sanad Hadits, 35 .

${ }^{23}$ Ibnu Shalah berkata dan ditetapkan oleh para imam setelahnya. Demikian sebagaimana dikatakan oleh ar-Razi tentang julukan shuduq "Haditsnya ditulis dan diteliti karena kata-kata ini tidak menunjukkan tanda-tanda dhabit." Maka haditsnya dipelajari dan diteliti hingga diketahui ke-dhabithannya. Lihat Nuruddi 'Itr, Ulumul Hadis, trans. Dr. Mujiyo "Manhaj an-Naqd fii 'Uluum alHadits”(Bandung: Remaja Rosdakarya, 2014),103.
} 


\section{Komparasi Derajat Ta'dil}

\begin{tabular}{|c|c|c|c|c|c|c|c|}
\hline Lafal & $\begin{array}{r}\text { Al } \\
\text {-Razi }\end{array}$ & $\begin{array}{r}\text { Ibn } \\
\text { Shalah }\end{array}$ & $\begin{array}{c}\text { Al- } \\
\text { Nawawi }\end{array}$ & $\begin{array}{c}\text { Al- } \\
\text { Dzahaby }\end{array}$ & $\begin{array}{r}\text { Al- } \\
\text { 'Iraqi }\end{array}$ & $\begin{array}{c}\text { Al- } \\
\text { Harawi }\end{array}$ & $\begin{array}{l}\text { Ibn Hajar } \\
\text { dan al- } \\
\text { Suyuthi }\end{array}$ \\
\hline أوثق الناس & & & & & & 1 & 1 \\
\hline ثقة ثقة & & & & 1 & 1 & 2 & 2 \\
\hline تُقة & 1 & 1 & 1 & 2 & 2 & 2 & 3 \\
\hline صدوق & 2 & 2 & & 3 & 3 & 3 & 4 \\
\hline لابأس به & 2 & 2 & 2 & 3 & 3 & 3 & 4 \\
\hline شيخ & 3 & 3 & 3 & 4 & 4 & 4 & 5 \\
\hline صالح الحديث & 4 & 4 & 4 & 4 & 5 & 5 & 5 \\
\hline لابأس أرجو أر & & & & 5 & & 5 & 6 \\
\hline
\end{tabular}

Keterangan:

1. Menurut al-Razi

Tingkat pertama : ثقة : لَأب

صدوق, لابأس به: $\quad$ Tingkat kedua

Tingkat ketiga : : لشيخ :

Tingkat keempat : صالح الحديث :

2. Menurut Ibnu Shalah

Tingkat pertama : بقة : بـ

صدوق, لابأس به : Tingkat kedua

Tingkat ketiga : : : :

Tingkat keempat : : صالح الحديخ :

3. Menurut al-Nawawi

Tingkat pertama : بقة : بر

Tingkat kedua : : لابأس به :

Tingkat ketiga : : :

صingkat keempat : صالح الحديث:

4. Menurut al-Dzahabi

ثقة ثقة : Tingkat pertama

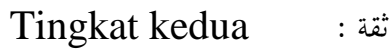

Tingkat ketiga : مدوق, لابأس به : Tha

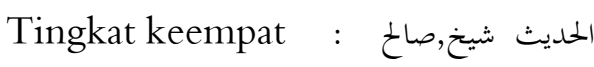

أرجو أن لابأس به : : Tingkat kelima

5. Menurut al-'Iraqi

ثقة ثقة : Tingkat pertama

Tingkat kedua ئة:

Tingkat ketiga : مدوق, لابأس به
شيخ : Tingkat keempat

Tingkat kelima : صالح الحديث :

6. Menurut al-Harawi

Tingkat pertama أوثق الناس

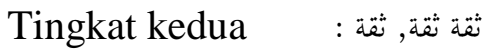

Tingkat ketiga : :

شيخ : Tingkat keempat

Tingkat kelima أرجو أن لابأس به :

7. Menurut Ibnu Hajar

$$
\text { صالح الحديث, الابن به : }
$$

Tingkat pertama

Tقة ثقة : الثق : Tingkat kedua

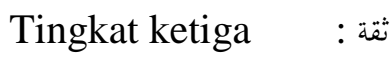

Tingkat keempat صدوق, لابأس به

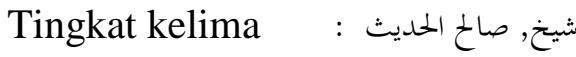

Tingkat keenam : :

8. Menurut al-Suyuthi

Tingkat pertama : أوثق الناس

Tingkat kedua : مقة ثقة :

Tingkat ketiga : مقة :

صدوق, لابأس به : Tingkat keempat

Tingkat kelima : : شيخ, صالح الحديث لاباسه :

أرجو أن لابأس به : Tingkat keenam 
Gambar tingkatan ta'dil

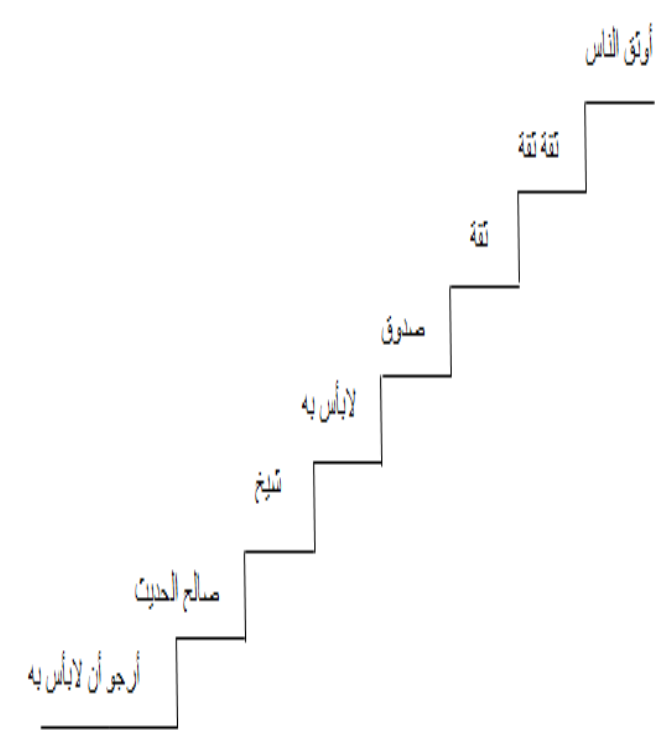

Dari uraian di atas tampaklah bahwa para imam sangat beragam dalam menilai para rawi baik dari sisi tajrih-nya maupun ta'dil-nya. Dengan demikian, ke-sighat-an para rawi dilihat dari kaca mata para jarih wa mu'addil sangat bergantung pada sudut tinjaunya masing-masing namun lepas dari permasalahan ini, ke-sighat-an menjadi maupun utama dalam otoritas periwayatan hadis. Dari kentataan ini, periwayatan bi allafzhi menjadi tolok ukur utama ke-istighatan rawi. ${ }^{24}$

\section{SIMPULAN}

Dari uraian makalah tentang perbedaan maratib ta'dil di kalangan ulama hadis dapat disimpulkan sebagai berikut :

1. Para ahli berbeda pendapat dalam menentukan martabat ta'dil.Ada yang mengklasifikasikannya menjadi empat, lima hingga enam.

2. Adapun tulisan yang pertama kali sampai kepada kita (Nuruddin 'Itr, hlm. 99), adalah karya tokoh kritikus alImam bin al-Imam Abdurrahman bin Abi Hatim al-Razi (w. $327 \mathrm{H}$ ), dalam

${ }^{24}$ M. Abdurrahman, \& Elan Sumarna, Metode Kritik Hadis, (Bandung: Remaja Rosdakarya, 2011), 158. kitabnya yang besar al-Jarh wa 'alTa'dil. Yang membagi martabat ta'dil ke dalam empat bagian.

3. Kebanyakan ulama hadis sepakat bahaw para rawi pada empat martabat pertama dapat dipakai hujah. Sedangkan para rawi pada martabatmartabat berikutnya tidak dapat dipaki hujah; karena lafazh-lafazh julukan bagi mereka tidak menunjukkan tandatanda ke-dhabith-an. Namun hadis meraka ditulis untuk i'tibar.

\section{DAFTAR PUSTAKA}

Al Quran al-Karim.

'Itr, Nuruddin, 'Ulumul Hadis, trans. Dr. Mujiyo "Manhaj an-Naqd fii 'Uluum al-Hadis". Bandung: Remaja Rosdakarya, 2014.

Abdurrahman, M., dan Elan Sumarna.Metode Kritik Hadis, Bandung: Remaja Rosdakarya, 2011.

Dimyati,Ayat.Pengantar Studi Sanad Hadis, Bandung: Fakultas Syari'ah IAIN Sunan Gunung Djati, t.t.

Jumantoro,Totok. Kamus Ilmu Hadis, Jakarta:Bumi Aksara, 2002.

Rahman,Fatchur.Ikhtisar Mushthalahu'l Haits, Bandung: al-Ma'arif, 1974.

Solahudin, M., dan Agus Suyadi.Ulumul Hadis, Bandung: Pustaka Setia, 2013. 
